\title{
Navigating religious diversity: Exploring young people's lived religious citizenship in
}

\section{Indonesia}

\author{
Ben K. C. Laksana ${ }^{1}$ and Bronwyn E Wood ${ }^{2}$
}

ARTICLE HISTORY Received 5 July 2018 Accepted 4 November 2018

Laksana, B. K. C., \& Wood, B. E. (2019). Navigating religious diversity: exploring young people's lived religious citizenship in Indonesia. Journal of Youth Studies, 22(6), 807-823. doi:10.1080/13676261.2018.1545998

\begin{abstract}
Against the backdrop of several concerning reports which have noted growing socio-religious conservatism and intolerance amongst Indonesia youth, this study examined how school-aged Indonesian young people navigate encounters with religious difference in their everyday lives. Recognising the significance of religious and citizenship education curricula, the research included classroom observations and interviews with 20 religiously-diverse Indonesian young people in three purposively selected high schools in Jakarta. The paper reveals that participants in all three schools agreed that religious studies and their personal religious frameworks were central to their approaches toward religious tolerance. However, their lived everyday experiences of rubbing shoulders with religious 'others', expanded upon and critiqued the narrowness and rigidity of these frameworks and showed greater religious inclusivity. Through this analysis the paper integrates prior work on 'lived religion' and 'lived citizenship' to fuse a 'lived religious citizenship' concept, arguing that this adds depth to both fields by recognizing that religion cannot be separated from the experience of being a citizen. A focus on lived religious citizenship provides a deeper account of individual identity and highlights the importance of qualitative studies focused on the living out of religion and citizenship.
\end{abstract}

Keywords: youth, citizenship, lived religious citizenship, lived citizenship, lived religion, Indonesia

\footnotetext{
1 Department of International Relations, International University Liaison Indonesia, BSD City, Indonesia.

2 Faculty of Education, Victoria University of Wellington, Wellington, New Zealand.
} 


\section{Introduction}

Growing levels of religious intolerance have been noted in many countries in recent years. For example, the Pew Research Centre (2014) reported a six-year peak of countries with a high, or very high, level of social hostilities involving religion in 2014. The report noted that religious hostilities increased in every major region of the world except for the Americas, and highlighted growing concerns in Egypt, Indonesia, Russia, Pakistan and Burma (Myanmar) where government religious restrictions are particularly high. The focus of this paper is on young people in Indonesia who represent a particularly interesting case - living within a religiously diverse, but predominantly Muslim nation and a fledgling democracy. Following the end of Suharto's authoritarian regime in 1998, evidence of growing religious intolerance, rising social conservatism, and violations of religious freedom and human rights have been documented by a range of both internal and external organisations (Human Rights Watch 2013; The Wahid Institute 2014, 2012; Human Rights Watch 2017; SETARA Institute 2016).

Young people have been particularly implicated in this in light of their apparent growing rates of religious intolerance. The release of two large-scale reports on Indonesian young people's levels of religious (in)tolerance have drawn particular concern. The first was a widely-discussed report by the Institute of Peace and Islamic Studies (LAKIP) in 2012 of 611,678 high school students in the Greater Jakarta. This revealed that $48.9 \%$ of students were willing to be involved in acts of religious violence, while $41.1 \%$ of students were willing to be involved in vandalising houses of worship of other religions (Jakarta Post 2012). LAKIP's survey also found that $25.8 \%$ of students deemed Indonesia's philosophical foundation the Pancasila, (which comprises five principles emphasising a nation under God, unity, democracy, and social justice), to be no longer relevant. The second, a more recent 2017 survey by the Centre for the Study of Islam and Society (PPIM) and Convey Indonesia of 1,522 students from 34 provinces throughout Indonesia, found that $51.1 \%$ of respondents 
had deeply intolerant views towards minority Islamic sects such as the Ahmadiyya and Shia communities (PPIM UIN Jakarta \& Convey Indonesia 2017). Additionally, $34.3 \%$ of the respondents had extremely intolerant views towards religions outside of Islam, with $58.5 \%$ of the students holding religiously radical views. The survey also found that $48.95 \%$ of the students felt that religious education has influenced them to not socialise with followers outside of Islam (PPIM UIN Jakarta \& Convey Indonesia 2017).

These large-scale studies both generated considerable debate and discussion in Indonesia and raised concerns about how the younger generation will deal with interreligious relations and issues of religious intolerance within Indonesia. The surveys signalled a rise in religious conservatism which has particular implications for young Muslims in Indonesia who are seen as both the targets and the agents of this Islamic resurgence (Parker and Nilan 2013). There is also evidence that young people - of various faiths - have been implicated in this and calls for public education to address this have been frequent (Syafirdi 2017; Tuasikal and Yuniati 2017).

Yet, while these reports give cause for great concern, their reliance on survey data of young people's perceptions and scaled responses reveal very little about how young people navigate daily encounters with religious difference in their everyday lives. This is despite a growing awareness in religious studies research about the significance of understanding the actual experiences of religious individuals and their everyday practices of religion or 'lived religion', rather than merely a focus on centralized understandings of religion (Ammerman 2007; McGuire 2008). Similarly, within youth citizenship studies, there is a growing awareness of the need to account for young people's everyday lived experiences of being citizens which occur through relational and daily acts of participation, care and belonging, rather than merely a focus on formal and public acts of citizenship (Kallio, Häkli, and Bäcklund 2015; Smith et al. 2005; Wood 2014; Lister 2003, 2007). Therefore, there is a need 
to counter these 'top down' surveys with qualitative 'bottom up' information about diverse religious Indonesian young people's everyday practices towards religious 'others' and how they understand these encounters in the context of their lived religion which is inseparable from their experiences of being a citizen of Indonesia.

The goal of this study was to examine young Indonesian's experiences of living with religious diversity, and through this to explore their everyday practices of 'lived religious citizenship' (Nyhagen 2015). Drawing on feminist approaches which foreground identity, belonging and participation, Nyhagen (2015) defines such an approach as a multifaceted one which 'acknowledges that rights, status, identities and participation, belonging and care are important dimensions of religious citizenship as lived practice' (p. 769). A key aspect of our study was to explore the representations of religion and citizenship within the contexts of both young people's formal schooling experiences and daily lives, and to consider how these experiences shaped their perceptions and practices of religious tolerance. . This involved an examination of the spaces within which young people practise their acts of citizenship and a consideration of how religion shaped these acts of citizenship and informed their 'lived religious citizenship'.

A secondary goal of the study was to interrogate the utility of 'lived religious citizenship' as a theoretical concept for youth studies in increasingly diverse and, at times, religiously acrimonious societies. This builds upon recent calls within youth studies research to integrate and enrich citizenship research within the dominant 'cultural' and 'transition' strands of youth studies (see, for example, Harris, 2009, 2015; Wood, 2017) in order to critique normative and limiting frameworks about how youth are perceived in society. This includes developing much more dynamic understandings of citizenship identities and how these are 'always contingent [upon social and political contexts] and continually negotiated, not only in youth but throughout the life-course' (Smith et al. 2005, 440). 
The paper proceeds as follows. As our focus is on school-aged Indonesian young people, we begin by outlining how religious tolerance is upheld in schools and in the school curriculum. This is followed by a deeper examination of the concepts of everyday lived citizenship and religious citizenship in order to establish the theoretical and conceptual underpinnings of this article. After an outline of the methodology employed, we then examine how Indonesian young people understood religious tolerance and how they navigated religious diversity in the contexts of their daily lives. The paper concludes with a discussion of the importance of everyday relational contacts in shaping attitudes and dispositions towards religious 'other' and the potential such experiences offer for fostering greater inter-religious understanding and civic engagement.

\section{Religion, religious tolerance and education}

Religion is an enduring feature of Indonesia's legal, civil and social spheres. It is an integral part of Indonesia's philosophical foundations, 'the Pancasila', as well as underpinning Indonesia's Constitution, and many laws (Maarif 2008). Yet despite this close relationship with religion, Indonesia is not a theocratic state. Instead, Indonesia prides itself as a free and democratic country which supports freedom of religion, as based on its 1945 founding Constitution. Yet despite this secular affirmation, the first of five principles of Indonesia's philosophical foundations, the Pancasila, explicitly states, "belief in one and only God". Parker (2008) suggests that in light of this statement, Indonesia is neither a secular state nor an Islamic/theocratic state, but it is a religious state. As a result, religion is closely entwined with the process of citizenship in Indonesia (Kuipers 2011).

This somewhat complex relationship with religion is also seen in the status of 'official religions' in Indonesia. The majority of the estimated population of over 240 million are 
followers of Islam (87.18\%), while the minority groups include Protestantism (6.96\%), Catholicism (3.1\%), Hinduism (1.69\%), Buddhism (0.72\%), with Confucianism 0.05\% and local indigenous beliefs held by $0.13 \%$ of the population (Badan Pusat Statistik [English translation] 2010). The majority of Indonesian Muslims follows the Sunni denomination, while a minority follow Shiah and Ahmadiyya traditions. Although Indonesia's constitution guarantees its citizens religious freedom, traditionally only six religions (i.e. Islam, Protestantism, Catholicism, Hinduism, Buddhism, and Confucianism), can be written in the religion section of Indonesia's national identity card colloquially known as the KTP (Kartu Tanda Pengenal). This is due to an archaic law - Law No.1/PNPS/1965 on religious defamation - which names these six 'official' religions. Whilst other religions are not prohibited, the default position is that only these six official religions have been sanctioned in subsequent human rights policy and legislations (Colbran 2010). While a recent (2017) Indonesian constitutional court decision has challenged these six 'official religions' and citizens are now allowed to also identify with indigenous beliefs on their identity cards (Allard and Damiana 2017), in general it is recognised that the state is authorized to determine not only the definition of religion, but also who has a 'religion' and who does not, thus producing a state-sanctioned, narrow definition of religion (Colbran 2010; Hefner 2013).

The complexity of this relationship towards religion is also illustrated by how the Indonesian state has gone about developing 'good' Indonesians citizens through national educational curricula. As Kennedy (2008) reminds us, the 'good' citizen is never a neutral nor apolitical term, but instead reflects certain ideological ideas. For Indonesia, this includes an explicit goal of national education to develop faith and piety towards the 'one almighty God, and good morality' in each student (Kementerian Pendidikan dan Kebudayaan [English translation] 2003), with the aim of constructing a 'godly nationalism' (Menchik 2016). While the majority $(87 \%)$ of the population are Muslim the state also recognises the need to reflect 
other theological frameworks in order to develop a religiously tolerant population, which they have done through development of religious and citizenship education curricula.

Within the national religious and citizenship education curricula, religious tolerance is defined as respect and acceptance of difference, not mere forbearance (Kementerian Pendidikan dan Kebudayaan 2003). However, interestingly, this religious tolerance is proposed in two different ways within these two curricula. Within the religious curriculum, religious tolerance relies upon multiple theological frameworks in which each of the six 'official' religions articulate a vision of a religiously inclusive community in line with their spiritual beliefs. In contrast, within the citizenship curriculum, the desire for religious tolerance is presented by referencing the secular foundations of the nation, i.e. the Constitution and national laws.

To illustrate how theological frameworks influence religious education for religious tolerance, the curriculum for Muslim students draws on the Qur'an. For example, it draws upon the most commonly employed verse from the Qur'an, 'lakum dinukum wa-liya dini', which translates to 'for you it is your religion, and for me it is my religion' (Chapter 109, verse 6) to inspire students to develop religious tolerance. ${ }^{3}$ Other religious curricula use a similar method (i.e. drawing from holy texts), to provide the justification in learning about religious tolerance. However, each of these multiple religious curricula applies a monoreligious model (Sterkens 2001) with the aim of confirming the internalisation of a particular religious tradition held by the students. So, a Muslim must study Islam, a Catholic must study Catholicism, a Hindu must study Hinduism and so on. Therefore, as having a religion is required by the state, Indonesian citizens must and will only formally learn from one single

\footnotetext{
${ }^{3}$ Add a bit more about this verse - as required by Review 2! For example, perhaps you could state something like - this verse is widely endorsed also outside of schooling contexts in Indinesia (?) at times of religious intolerance to justify more of an acceptance of other religious beliefs ????
} 
religion and not another. Through this model of learning religion, Bagir (2008) cautions that the superiority of the student's religion may be implied when other religions outside the students' are discussed and although religious diversity is acknowledged, religious knowledge are kept isolated from one another.

In contrast to this, teaching for religious tolerance within the citizenship education curriculum draws from secular perspectives, relying, for example, on Indonesia's Constitution and laws concerning human rights and religious freedom, most specifically, employing article 29 of the Constitution which states:

1. [The] state is based upon the belief in one supreme God.

2. The state guarantees the freedom of each citizen to embrace each religion and to worship according to his/her religion or belief.

The legislative underpinning support of religion and religious freedom shows how the state tries to find a contradictory, yet middle ground in which religion and secular laws affirm one another. It does so by seeking to establish the idea that Indonesian citizens can legitimize their inclusive citizenship values, such as religious tolerance, through both their religion and the more secular national laws. However, this is an inherently contradictory position: on one hand the citizenship curriculum supports young people to develop a national identity which is inclusive and respectful of other religions; on the other hand, the religious education curriculum promotes a religious identity found through one's own religion not anyone else's.

In addition, a state-sanctioned method to avoid religious conflict also exists, known by the acronym SARA: with stands for ethnicity (suku), religion (agama), race (ras) and interclass (antar-golongan) differences: "to encapsulate the four sensitive areas that could not be discussed in public" (Hefner 2013). Topics that touch on these four areas are often instantly labelled SARA and deemed inappropriate to discuss further. The end result is that 
possible conflicts between some religious and secular notions of religious tolerance and pluralism remains largely unexamined and students are not encouraged to interrogate more complex and contradictory elements of these principles when forming their notions of religion and citizenship. Our study was particularly interested in this internal contradiction and how it played out in the lives of young religiously diverse people both within schooling contexts and outside, and how this shaped up as a form of 'lived religious citizenship'.

\section{Youth, religion and everyday citizenship}

While 'religious citizenship' has previously been coined to convey the rights of religious individuals as citizens (such as an individual's claim to their religious clothing, holidays and practices at work, (for examples, see Hudson 2003; Permoser and Rosenberger 2009), the concept of lived religious citizenship is a relatively new one. Nyhagen (2015) suggests that this term has gained momentum alongside a desire to recognize the differentiated nature of citizenship and its multiple (political, social, cultural, gendered etc.) dimensions. Nyhagen associates the origins of this term with the feminist goals of conceptualising citizenship in terms of lived practice, alongside parallel developments in the sociology of religion which emphasise religion as a lived practice in daily life. Nyhagen argues that adding the dimension of 'lived' practice involves a shift away from a narrow focus on status, formal institutional practices and rights, to one that is characterised by a growing interest in the practices and actions of people in their everyday lives. This shift can be traced through literature in both religious and citizenship studies.

The development of 'lived religion', is heralded by authors such as Ammerman (2007) and McGuire (2008) who suggest that contemporary religious views and practices can no longer be defined through a narrow lens of participation in religious institutions, but 
instead religion needs to be seen as the everyday practices of ordinary individuals. 'The lived experience of religion,' Levine $(2012,8)$ writes, 'is closely linked to ways of managing ordinary life.' So thus,

it is not just that religious beliefs spill over from neatly confined church spaces to infuse action in other parts of life. On close inspection, the distinction between otherworldly and this-worldly, between committed and spiritual, does not hold up very well.

Lived religion is therefore understood not simply through the status, rights and institutionalized practices of religious persons, but through the emotions and performances experienced in their everyday life which are 'grounded in the everyday ways modern persons relate to the things they experience as religious or spiritual' (Ammerman 2007, 5). This notion of lived religion becomes especially noteworthy as contemporary citizenship encompasses civil, cultural, social areas and hence the emergence of new forms of citizenship such as religious citizenship.

The development of notions of lived religion has been paralleled by an interest in ‘lived citizenship'. Within youth citizenship studies, there has been growing dissatisfaction within youth citizenship scholarship with the narrow and limiting frameworks which have traditionally been used to examine young people's citizenship dispositions and actions. These traditional frameworks frequently analyze the status, rights and responsibilities of young citizens, and conclude that as young people do not participate in certain activities - such as joining political parties, voting, and signing petitions - they are not regarded as full citizens (Wood, 2014; Lister 2003). However, these measures are normative and exclusive and often fail to consider young people's differences in capacity, independence and access to resources from adults (Lister 2003). Moreover, adult-defined and formal measures of citizenship 'success' fail to consider the diverse and varied ways that young people themselves may 
enact their sense of citizenship in the context of their daily lives. This has led to a body of research which seeks to uncover these 'everyday' forms of citizenship in often mundane and informal spaces (Kallio, Häkli, and Bäcklund 2015; Harris and Wyn 2009; Wood, 2014). Moreover, such approaches unveil the potential for such mundane spaces and acts to also be sites of political possibility, as we can understand 'how everyday life can also operate as an arena for the contestation and transformation of dominant, often oppressive modalities of citizenship' (Dickinson et al. 2008, 105).

Yet, despite these mutual pathways which both seek more flexible and 'everyday' understandings of citizenship and religion, only a few studies have brought these together to consider explore 'lived religious citizenship'. A small number of studies illustrate how this integration can shed fresh understandings of both religious and citizenship practices. For example, drawing on a study of Latin America's crisis zones, Rubin et al. (2014) argue that secular research on social movements and citizenship all too often overlooks the role of religion in creating 'the politics of the governed' (applying Chatterjee's (2006) understanding of this). They suggest that citizenship, as it is lived in Latin America's crisis zones, is permeated by rituals, symbols and practices of religion - and that these cannot be separated from the experience of being a citizen. Recognising this sheds light on 'the ways religion can both foster and limit the progressive reform sought by social movements' (9) and additionally the contribution of religion to resist, subvert and express forms of citizenship. Similarly, Nyhagen's (2015) utilisation of lived religious citizenship in her study of Muslim and Christian women in Norway and England enabled her to provide a deeper account of the everyday experiences of religious individuals which are intertwined with their sense of belonging and participation to a multitude of identities through their lived citizenship practices.

Our research sought to build upon these studies and to consider what a lived religious 
citizenship approach could offer for deeper understandings of youth growing up in a multireligious nation like Indonesia. In this study, we employed conceptions of lived citizenship and lived religion that aimed to be more generous, inclusive and diverse to account for young people's experiences. Examining lived citizenship and lived religion together provides an opportunity to observe what Dewey (1916) explains as 'everyday' experience, reflection and meaning-making. Our aim was to explore the overlap of both everyday understandings of citizenship and religion, as well as young citizens navigation between their citizenship and religious identities. Furthermore, we attempted to explore lived religious citizenship as an experiential, emotional, flexible process that concerns an individual's multi-layered identities and loyalties to their family and communities (Jackson 2015; Yuval-Davis 1999; Ho 2009; Wood, 2013; Lister 2003).

\section{Research Methodology}

In order to explore different interpretations of religious and citizenship education alongside young people's practices of inter-religious interaction, a qualitative study applying a range of methodological tools was conducted within three purposively selected high schools in Jakarta. Jakarta was chosen as the site for the research as it is Indonesia's most populated city and the site of the two surveys studies discussed earlier. In addition, the first author had prior experience of living in Jakarta which made fieldwork negotiations smoother and enabled deeper insights into data.

The study employed a multiple case study approach through the purposive selection of three secondary schools (Stake, 2006). The first school was an Islamic day school, more commonly known as a Madrasah, which used the National Curriculum with an additional Islamic curriculum with a focus on Islamic religious education, Arabic language, Islamic 
jurisprudence, Islamic culture, history and studies of the Al-Quran. For the purposes of this study this is named Jakarta Madrasah High. The second school, Jakarta Public High, was a state-run public high school that solely utilised the National Curriculum. The third school, a privately-run high school, Jakarta National High, used the National Curriculum, but in keeping with the nationalistic ideology of their school's founder, placed a strong emphasis on Indonesia's state ideology and constitution (see Table 1 for a summary). In order to maintain some similarity across the quality of education these schools, all selected schools had an 'A' grade level of certification to ensure consistency of quality across the three schools. ${ }^{4}$

\section{[Table 1 approx here]}

Data collection included both ethnographic and interview methods and were undertaken by the first author who is fluent in the language of Bahasa Indonesia. The ethnographic data included time in the selected secondary schools observing religious and citizenship education classes in each school. These observations were supplemented by secondary data from the schools, such as official documents, websites, lesson plans and teaching guidelines to supplement and confirm perceptions of participants in each school, and the broader school culture and practices. Data in this paper is largely drawn from interviews with participants in the three schools. The first author interviewed all religious education and citizenship education teachers in each school. Students were also invited to participate in focus group discussions. Twenty young people, aged 16-19, opted in to the study with the majority from Islamic religious backgrounds, reflecting both Jakarta as well as Indonesia's predominant religious affiliation. A smaller number of participants were Christian and there were nine male and eleven female student participants (Table 1). Focus group discussions

\footnotetext{
4 Schools in Indonesia are certified A, B, or C by the government as an assessment of quality.
} 
occurred during school hours and lasted from 30 minutes to one hour. Each group consisted of six to seven students. Participants completed a number of posters and mind maps in pairs before the interview in order to allow time for quieter students to think and reflect on the issues and to minimise the potential for outspoken members to dominate (Berg and Lune 2012).

A key challenge of the research was to create opportunity for young people to discuss the sensitive topic of religious issues honestly and without causing discomfort. To do this, a 'secret box' technique was also used which involved participants anonymously writing down their thoughts or ideas and then posting their responses into a box when done (Punch 2002). This strategy was used immediately following the focus group interviews to allow students to raise other issues or add more on 'hot' topics. Most students either reiterated or expanded on the points they made in the interviews, while some discussed more of their personal experiences regarding religious diversity.

All interviews were conducted in Bahasa Indonesia and the first author then transcribed and translated these from Indonesian into English, using meaning-based translations, rather than word-for-word translations (Esposito 2001). Data were then organised and condensed and coded thematically in order to establish and make sense of possible patterns. We began by looking for recurring regularities in the data which could then be sorted into categories (Patton 2002). We also used the research questions as a framework to support the analysis and focus on key aspects (Burton, Brundrett, and Jones 2008). We also examined themes that were particular to one high school (within-case analysis), as well as a cross-case analysis of themes to identify unifying these across the cases (Creswell 2012). Data from the secret box activity and secondary data were also incorporated to further explore the perceptions of teachers and students and confirm patterns and themes. This process of triangulation was also done to guard against over-generalising the opinions 
expressed in the focus group, as well as oversimplifying complex discussions (Barbour 2008) (see Laksana, 2014 for further details). The small number of participants in the study meant it was difficult to draw generalisable patterns from this data, including on aspects of gender, ethnicity and social class. However, given these limitations and the need for a larger-scale project to confirm them, the study provides interesting insights into what it meant to live and navigate inter-religious diversity for these participants.

\section{A religious framework for citizenship values}

With the introduction of mandatory religious studies in Indonesia, religion has become one of the essential ways students learn about inclusive values such as tolerance (Parker \& Nilan, 2013). This was commonly reported by participants who saw religion as an essential part of life, and the learning of religious tolerance through schooling as a key source of the values they held. For example, Gege (female, Muslim, 18yrs), a student from Jakarta Madrasah High, described:

Maybe for Islam, we see that religion is a guide in our lives, we use the Qur'an and the Hadith. In our everyday lives, maybe morals are values from such as the things we learn in sociology. Moral values in society are cultural values but still, the first is from religion. The thing is we learn about tolerance from studying religion. (Gege, Muslim, $18 \mathrm{yrs})$

Similar to Gege, Susi (female, Muslim, 18yrs) from Jakarta Private High agreed on the significance of religion: "Well moral values are based on religion "because" (English word used) religion "is everything" (English words used). If we don't have religion what should we do?' Adhung (male, Muslim, 16yrs) from Jakarta Madrasah High elaborates on why religion 
is necessary if students are to learn about inclusive values:

Studying religion is broad, not everything is just about religion. Because Indonesia is so diverse we also study tolerance between people, so that we can value other peoples' feelings...so that we don't become negative to them. It's important for our diverse society.

Meanwhile Nolan (female, Muslim, 16yrs), from the Jakarta Public High, saw being an Indonesian and being religious as inseparable: 'religion is important because in Indonesia's culture, religion has become the most fundamental guide in living life including when interacting with people.' She reflected that religion was a key attribute of her identity and that while she was still a teenager, she used religious frameworks to help navigate daily life, even though later in life "when I enter society it will make better "sense" (English word used), for now, it's just like that.' Agreeing with Nolan, Gse (female, Protestant, 16yrs) goes on to describe this in greater detail, arguing that religious tolerance was a key attribute of Indonesian culture that cut across all religious positions: 'From TV shows there are many bigoted things, like talking badly of other religions. If a small kid sees this they will be violent towards their friends. This is not Indonesia's culture.'

These responses of the students show how religion studies and religious frameworks were a defining factor for acquiring and maintaining their own values and approaches to religious 'others'. Religion was seen as a central source in defining how they should act within their daily lives as Indonesian citizens. This echoes prior research in Indonesia by Parker and Nilan $(2013,7)$ who also found strong links between Indonesian young people's religion and their stated values, with young Muslims regularly asking themselves moral questions linked to their religion, such as 'Is this what a good Muslim would do?' 
Although the majority of the students agreed on the necessity of religion in constructing and maintaining their life values, a small number of students critiqued the mono-religious frameworks they were taught and drew on alternative frameworks - primarily derived from their own personal experiences in understanding the role of religion. For example, Dede (male, Muslim, 16yrs) a student from the Jakarta Public High observed:

Well I don't support that values must be from religion. When I saw the Japanese tsunami, I know that many Japanese do not have a religion. Watching the news, they were very orderly, evacuating in order, even if religion is not something principal for them. If we look at Indonesia most are Muslims, the lack of moral values can be seen, most are bad.

Dede's account provides a critique of how civic values within Indonesia can still be inadequate even if drawn from religious views, which prompted him to question whether religion was the primary and only site that students used to form their values and actions. Dede's peer Gse, (female, Protestant, 16yrs) reaffirmed Dede's view, explaining: “I think people can have morals, be kind and polite even if they don't have a religion. I think they can.”

Several from Jakarta National High, reflected this outlook as well, as Vino (Male, Muslim, 16yrs) noted, 'I have a friend who is a westerner and for westerners their morals are based on law right? That means their religion is the law. That I think can work.' Echoing Dewey's (1916) view of how knowledge is experientially constructed, these young people showed how they constructed their own knowledge and understanding of the religious and citizenship values through their own daily experiences. These discussions highlight that while religion was central in shaping these participants' perspectives on religious diversity and tolerance, understandings of religion were not merely acquired and accepted without 
critique, but instead, were constructed, shaped and formed through lived personal experiences as well.

\section{Relational and lived experiences of religious diversity}

Although acknowledging and affirming the salience of religious frameworks in shaping their values, many of the youth participants also drew strongly on their everyday lived experiences of interacting with diverse religious peers and community members to establish their views on religious tolerance. This was seen during the focus group interviews as well as through the responses given in the secret box across the three schools. Students from Jakarta Madrasah High, for instance, showed how everyday personal and family experiences contributed to their understandings as well as affirming the importance of religious tolerance. For many this included a belief in cross-religious friendships:

In our everyday lives, the bond of religion and tolerance is very tight. Why? Because religion without tolerance will not go well in many life problems and interactions between people. In finding a friend we should not look at their religion, we should remain together even if we have different religion. (Jakarta Madrasah High, secret box)

In the following excerpt, Kingdom, a 16-year-old Muslim female, elaborates how her family's experiences in engaging with religious diversity led to more inclusive and tolerant views:

I have a cousin who got married to someone that has a different religion and $\mathrm{s} / \mathrm{he}^{5}$ changed his/her religion. I asked my parents, if I should hate him/her for this? My

\footnotetext{
5 Pronouns are ambiguous to protect the participant.
} 
parents said no you don't, because we live in Indonesia not an Islamic country. Even if the majority are Muslims, there are other religions as well. Indonesia is a country based on laws. You can't force someone's religious views because we have laws for religious freedom. My parents told me to think about the good things I can do for my religion. My religion is my religion, your religion is your religion [citing the Qur'an verse discussed earlier].

Kingdom's experience in religious diversity, coupled with her parent's mediation, emphasised Indonesia's secular laws as the primary guide in approaching religious diversity, even though she still returns to her religious framework to then confirm this position (by citing a religious verse from the Qur'an). This demonstrates how even if religion does play a central aspect in the formation of her values, it was reinterpreted in light of her own and her family's lived experiences of welcoming in a religious 'other'. Another student from Jakarta Madrasah High, Adhung (male, Muslim, 19yrs), shared how he similarly learned and acted upon dealing with religious diversity through his personal inter-religious interactions with friends:

My house is near a friend that has a different religion than I do, and we hang out often. I learned religious tolerance from there, from hanging out. My family is Muslim but my friends, the people I hang out with, are different. Even if I'm a Muslim I often think that many other religions are nicer than us. We can't say which one is the best one. Which one is the correct one, Christians or Muslims?

Despite being taught religion through a mono-religious model in the Madrasah, Adhung's daily interactions provided him with a critical approach to navigating diversity in his daily life which expanded upon the mono-religious foundations of his school. These personal experiences led Adhung to begin to question the normativity of his school's method in teaching religion alongside notions of his religion's dominance and superiority. This 
questioning about his religion's theological dominance when juxtaposed with his lived experiences of religion led him to conclude with a state of equality between religions. Adhung's classmate at the Madrasah, Nuy (female, Muslim, 16yrs), also shared a similar experience:

I have a neighbour who is a Christian. When we've done something wrong s/he gives an answer/advice based on his/her religion. We respect that and if s/he's done wrong we will also explain it to him/her based on our religion. So, we respect one another.

These experiences of Kingdom, Adhung and Nuy illustrate the salience of their everyday experiences in engaging religious diversity, revolving around the mutual feeling of respect and friendship. Their perceptions are significant when considering they attend a conservative Madrasah yet hold a deep sense of inclusivity towards religious others (Fieldnotes, 2014). Through primarily positive social and relational interactions, they demonstrated and practised inclusive citizenship values and actions. This does also raise the potential for less positive outcomes to also arise if sociali relations sour or result in misunderstandings.

The majority of responses from the participants across the three schools saw tolerance as an important value in navigating issues arising from religious diversity. However, there was a surprisingly level of critique of how this was taught both with the religious and citizenship education programmes in focus groups interviews. Some critique was expressed, however, primarily within the 'secret box' activity which allowed for anonymity. For example, Anonymous Student A from Jakarta Public High was critical of the mono-religious approach and the right/wrong position this created:

I think religious tolerance in Indonesia is quite bad, not only between religions but specifically within a religion itself. It is as if we do not know what we should do when 
faced with difference. Many still think 'I am right, and you are wrong'. In many ways, I think the reason for this is because religious tolerance is not acted on enough in schools. It should be a different subject from religion and civics.

Another anonymous student (B) from Jakarta Public High also critiqued the dominant way that religion was conveyed (as a single identity) and how religious tolerance was taught:

Indonesians generally still see their religion as their identity and as something they must defend. But this has produced a fanatical, narrow mind-set where every individual assumes that their faith is the truth or the most correct and the faith of others is wrong. This has triggered minor discriminations such being as exiled or excommunicated from society and also perhaps heavy forms of discrimination such as the closure of religious places by force and physical violence. This I think causes riots in many parts of Indonesia. (Anonymous Student B, Jakarta Public High)

Another student, Anonymous C from Jakarta Public High, was even more critical of the government's approach to the issue of religious discrimination in Indonesia:

Indonesians argue a lot about religious differences. Even the government is weird, I sometimes feel that they see that Islam is the truest religion. If a so called 'false religion' shows up, it will immediately be banned. But no one sees Islam as a false religion. To be honest I do not understand what our government's rights are; why does our government have the ability to ban people from embracing the religion which they see as true? Why does everyone have to bow down towards laws if those laws push them away from the God they believe in? That means the government, with their laws, has brought society down a path that could be wrong. Indonesia is weird. Indonesia needs a lot of fixing.

These three participants anonymously critiqued the contradictions inherent in their school 
curricula and state policies, raising concerns that these approaches were far from successful on addressing religious intolerance and discrimination. Their comments highlight the frustrations with the SARA policy which shut down opportunities for discussion and debate. They demonstrate an active awareness and engagement with social and political issues relating to the challenges of religious diversity in Indonesia. However, at no time are their responses aligned to acts of violence towards others as the large surveys cited earlier would suggest. Instead, they demonstrated critical and thoughtful responses, which were deepened by their friendships and daily lived experiences of multiple inter-religious encounters.

\section{Discussion and Conclusion}

This paper took as its lens an 'everyday' look at young people's lived citizenship and religion in Indonesia. By exploring the everyday way young Indonesians navigated diversity, we can see that although for many young people religious frameworks were indeed a basis for their views on citizenship, their everyday lived experiences of religious diversity also significantly shaped and reinforced their citizenship values and actions. This was illustrated significantly by responses from Islamic students from the Madrasah who could have been expected to hold the most conservative and exclusive views towards religious 'others'. In addition, many participants were highly critical of the narrowness and rigidity of their religious and citizenship education experiences and were dissatisfied with holding these as the only frameworks for approaching religious tolerance in their daily lives. They showed how their citizenship identities could closely align with their religious identities thus upholding an allegiance towards the nation-state along with its inclusive democratic values, as proposed by Irving (2007). In our study this involved an iterative negotiation between the sacred and the profane, affirming what Pohl (2011) describes as the potential of drawing from both the positive elements of religion and the more secular sources. 
Additionally, our study highlighted the significance of the relational and affective aspects of young people's daily experience with inter-religious relations. These centred on their daily encounters with peers and community members, suggesting a less fixed and normative notion of citizenship, and instead one which was 'continually negotiated' (Smith et al., 2005, p 440). These responses confirm Johansson's (2008) finding which showed a degree of freedom within which young people draw their values from in establishing what it means to be a good religious citizen. Similar to Ryan's $(2013,458)$ study of Muslim youths in London, we found that 'rather than a single theology, young people seem to blend various, competing influences' including citizenship. This signalled a more fluid, do-it-yourself (DIY) construction of their views of citizenship, as noted by Harris and Roose (2013), that was connected with elements of their religion. These examples from Indonesian young people also point to much richer understandings of both citizenship and religion where personal experiences are central to understanding an individual's sense of lived citizenship (Lister 2007) and lived religion (Ammerman 2007).

Religion did indeed strongly infiltrate many aspects of young people's citizenship actions and dispositions. Additionally, linking religion with one's citizenship led to 'a far meaningful and richer context for identity development' (Durrani and Dunne 2009, p. 235) as shown by many participants in this study. Following feminist approaches which expand religious citizenship beyond status, rights and practice and focus on the subjective nature of citizenship through daily lived experiences (Osler and Starkey 2005; Lister 2003; Nyhagen 2015), this study demonstrated how relational interactions across religiously diverse people helped to inform and establish young people's inclusive citizenship actions and identities. In turn, these embodied experiences also shaped how they themselves perceived their own status, practice and rights as citizens. Rather than studying religion separately from citizenship, our study showed how these two aspects were inseparable, and that a lived 
religious citizenship approach shed light on the way that religion could both foster more inclusive religious tolerance, as well as at times reduce it (Rubin, Smilde, and Junge 2014).

While this was a small-scale study, the practices of lived religious citizenship illustrated by these young Indonesians critique many assumptions about youth generated by the large-scale surveys referred to earlier in this paper which had suggested that the majority were intolerant and discriminatory toward other religious groups (see also PPIM UIN \& Convey Indonesia 2017; SETARA Institute 2016 for similar findings). This merits further investigation as a significant challenge for Indonesia still remains, which is to consider how open, amicable inter-religious interactions could happen in a daily and natural way, given the growing segregation of communities in many Indonesian cities today. Given that the majority of Indonesians are Muslims, and that a great number of them have limited encounters with people of different religions, it is likely that educational settings could emerge as strategic sites for young people to learn to navigate both religious and citizenship identities in the context of diverse others, as data from this research shows. Beyond this study, we suggest that further investigations are needed if we are to advance our understanding of the intricacies of young Indonesian's lived religious citizenship and thus provide a more complete picture of how young people in Indonesia navigate inter-religious diversity.

Theoretically, the paper confirms the salience of the notion of lived religious citizenship, established by Nyhagen (2015) and others. The advantage of such this integrated concept was demonstrated in our study by how it shed light on wholistic experiences of being a citizen which reflected both 'lived citizenship' and 'lived religious' experiences simultaneously. Our study also and extends upon earlier research in this area (e.g. Nyhagen, 2015; Rubin et al., 2014) by demonstrating the significance of everyday relational interactions and how these can serve to enrich and widen our knowledge of both religion and citizenship. In addition, the study contributes to informing more complex notions of 
citizenship construction in a multi-religious (and often conflicted) society and how this is lived through everyday religious citizenship practices. 


\section{References}

Allard, Tom, and Jessica Damiana. 2018. "Indonesian court recognizes native religions in landmark ruling." Reuters, Accessed 12 April. https://www.reuters.com/article/usindonesia-religion/indonesian-court-recognizes-native-religions-in-landmark-rulingidUSKBN1D71J2.

Ammerman, N. T. 2007. "Everyday Religion." In, edited by N. T. Ammerman. Oxford: Oxford University Press.

Badan Pusat Statistik. 2010. "Penduduk Menurut Wilayah dan Agama yang Dianut." In. Jakarta: Badan Pusat Statistik.

Badan Standar Nasional Pendidikan. 2006. "Standar isi KTSP 2006." In, edited by Badan Standar Nasional Pendidikan - Kementerian Pendidikan dan Kebudayaan. Jakarta: Badan Standar Nasional Pendidikan.

Bagir, Zainal Abidin 2008. "Interfaith dialog and religious education." In 4th Asia-Europe Meeting (ASEM) Interfaith Dialogue. Amsterdam, Netherlands.

Berg, Bruce, and Howard Lune. 2012. Qualitative research methods for the social sciences. Boston: Pearson Education, Limited.

Burton, Neil, Mark Brundrett, and Marion Jones. 2008. Doing your education research project: SAGE Publications.

Chatterjee, Partha. 2006. The politics of the governed: Reflections on popular politics in most of the world. New York: Colombia University Press.

Colbran, Nicola. 2010. "Realities and challenges in realising freedom of religion or belief in Indonesia." The International Journal of Human Rights 14 (5):678-704. doi: 10.1080/13642980903155166.

Dewey, John. 1916. Democracy and education: An introduction to the philosophy of education. New York: Macmillan.

Dickinson, Jen, Max Andrucki, Emma Rawlins, Daniel Hale, and Victoria Cook. 2008. "Introduction: Geographies of everyday citizenship." ACME: An International EJournal for Critical Geographies 7 (2):100-12.

Durrani, Naureen., and Mairead. Dunne. 2009. "Curriculum and national identity: exploring links between religion and nation in Pakistan." Journal of Curriculum Studies 42 (2):215-40. doi: 10.1080/00220270903312208.

Esposito, Noreen. 2001. "From meaning to meaning: The influence of translation techniques on non-English focus group research." Qualitative Health Research 11 (4):568-79. doi: $10.1177 / 104973201129119217$.

Harris, A. (2009). Young, people, politics and citizenship. In A. Furlong (Ed.), Handbook of youth and young adulthood: New perspectives and agendas (pp. 301-306). Oxon/NY: Routledge.

Harris, A. (2015). Transitions, cultures and citizenship: Interrogating and integrating youth studies in new times. In D. Woodman \& A. Bennett (Eds.), Youth cultures, transitions and generations: Bridging the gap in youth research (pp. 84-98). Houndshill/NY: Palgrave Macmillan.

Harris, Anita, and Joshua Roose. 2013. "DIY citizenship amongst young Muslims: experiences of the ordinary." Journal of Youth Studies 17 (6):794-813. doi: https://doi.org/10.1080/13676261.2013.844782. 
Harris, Anita, and Johanna Wyn. 2009. "Young people's politics and the micro-territories of the local." Australian Journal of Political Science 44 (2):327-44.

Hefner, Robert. 2013. "The study of religious freedom in Indonesia." The Review of Faith \& International Affairs 11 (2):18-27. doi: 10.1080/15570274.2013.808038.

Ho, Elaine. 2009. "Constituting Citizenship Through the Emotions: Singaporean Transgmigrants in London." Annals of the Association of American Geographers 99 (4):788-804.

Hudson, Wayne. 2003. "Religious citizenship." Australian Journal of Politics and History 49 (3):425-9.

Human Rights Watch. 2013. "In religion's name: abuses against religious minorities in Indonesia." In. USA: Human Rights Watch. . 2017. "Indonesia: Country Summary 2017." In, edited by Human Rights Watch. Human Rights Watch.

Irving, Helen. 2007. "Citizenship, statehood and allegiance." In Managing diversity: Practices of citizenship, edited by L. Cardinal and N. Brown. Otawa: University of Ottawa Press.

Jackson, Lucy. 2015. "Intimate citizenship? Rethinking the politics and experience of citizenship as emotional in Wales and Singapore." Gender, Place \& Culture:1-17. doi: 10.1080/0966369X.2015.1073695.

Jakarta Post. 2013. "Moderate Islam on the brink against radicals." The Jakarta Post, Accessed September 14. http://www.thejakartapost.com/news/2012/06/25/moderateislam-brink-against-radicals.html.

Johansson, Thomas. 2008. "Schooling, religion, youth and everyday life: Learning processes in an independent Muslim school environment." Young: Nordic Journal of Youth Research 16 (4):373-91. doi: 10.1177/110330880801600402.

Kallio, Kirsi Pauliina, Jouni Häkli, and Pia Bäcklund. 2015. "Lived citizenship as the locus of political agency in participatory policy." Citizenship studies 19 (1):101-19. doi: 10.1080/13621025.2014.982447.

Kementerian Pendidikan dan Kebudayaan. 2003. "Undang-undang Republik Indonesia no. 20 tahun 2003 tentang sistem pendidikan nasional." [English trans] In. Jakarta: Kementerian Pendidikan dan Kebudayaan.

Kennedy, Kerry. 2008. "The citizenship curriculum: Ideology, content and organisation." In The Sage Handbook of Education for Citizenship and Democracy, edited by James Arthur, Ian Davies and Carole Hahn, 483-91. London: Sage.

Kuipers, Joel C. 2011. "Religion and worldview." In Indonesia a country study, edited by William H. Frederick and Robert L. Worden, 118-26. Washington D. C.: Federal Research Division Library of Congress.

Laksana, Ben K. C. 2014. "Living Together in a Religiously Plural Society: Indonesian Teachers' and Students' Perceptions on Citizenship, Identity and Religious Tolerance." Master's thesis, Victoria University of Wellington.

Levine, Daniel H. 2012. Politics, religion, and society in Latin America. . Boulder, CO: Lynne Rienner Publishers.

Lister, Ruth. 2003. Citizenship: Feminist Perspectives. 2nd ed. New York: Palgrave Macmillan. 
2007. "Inclusive Citizenship: Realising the potential." Citizenship Studies 11 (1):4961.

Maarif, Ahmad. 2008. "Islam and democratization in Indonesia." In Islam beyond conflict: Indonesian Islam and western political theory, edited by W. Hudson and A. Azra. Burlington, USA: Ashgate Publishing Company.

McGuire, Meredith. 2008. Lived religion: Faith and practice in everyday life. Oxford: Oxford University.

Menchik, Jeremy. 2016. Islam and Democracy in Indonesia: Tolerance without Liberalism. New York, New York: Cambridge University Press.

Nyhagen, Line. 2015. "Conceptualizing lived religious citizenship: a case-study of Christian and Muslim women in Norway and the United Kingdom." Citizenship studies 19 (67):768-84. doi: 10.1080/13621025.2015.1049979.

Osler, Audrey, and Hugh Starkey. 2005. Changing Citizenship: Democracy And Inclusion in Education. New York: Open University Press.

Parker, Lyn, and Pam Nilan. 2013. Adolescents in contemporary Indonesia, Routledge contemporary Southeast Asia series. London ; New York: Routledge.

Permoser, Julia., and Sieglinde. Rosenberger. 2009. "Religious Citizenship as a substitute for immigrant integration? The governance of diversity in Austria." In Illiberal Liberal States, edited by E. Guild, K. Groenendjik and S. Carrera. Aldershot: Ashgate.

Pew Research Centre. 2014. "Religious Hostilities Reach Six-Year High." In. Washington DC, US: Pew Research Centre,.

Pohl, Florian. 2011. "Negotiating religious and national identities in contemporary Indonesian Islamic education." Cross Currents 61 (3):399-414.

PPIM UIN Jakarta \& Convey Indonesia. 2017. "Api dalam sekam: Keberagaman gen Z." In Survei Nasional tentang Sikap Keberagamaan di Sekolah dan Universitas di Indonesia, 10. Jakarta: PPIM UIN Jakarta dan Convey Indonesia.

Punch, Samantha. 2002. "Interviewing strategies with young people: The 'secret box', stimulus material and task-based activities." Children and Society 16 (1):45-6.

Rubin, Jeffrey W., David Smilde, and Benjamin Junge. 2014. "Lived religion and lived citizenship in Latin America's zones of crisis." Latin American Research Review 49:7-26.

Ryan. 2013. "'Islam does not change': young people narrating negotiations of religion and identity." Journal of Youth Studies 17 (4):446-60. doi: 10.1080/13676261.2013.834315.

SETARA Institute. 2016. "Laporan Survei Toleransi Siswa SMA Negeri Jakarta dan Bandung Raya." In, edited by SETARA Institute, 34. Jakarta: SETARA Institute.

Smith, Noel, Ruth Lister, Sue Middleton, and Lynne Cox. 2005. "Young people as real citizens: Towards an inclusionary understanding of citizenship." Journal of Youth Studies 8 (4):425-43.

Stake, R. (2006). Multiple case study analysis. New York: The Guilford Press.

Sterkens, Carl. 2001. Interreligious learning: The problem of interreligious dialogue in primary education. Boston: Brill.

Syafirdi, Didi. 2018. "Pendidikan karakter dinilai jadi benteng menangkal paham radikal." [English trans] Merdeka, Accessed 13 April, 2018. 
https://www.merdeka.com/peristiwa/pendidikan-karakter-dinilai-jadi-bentengmenangkal-paham-radikal.html.

The Wahid Institute. 2012. "Laporan akhir tahun kebebesan beragama dan intoleransi 2012." [2012 annual report on freedom of religion / belief and issues of intolerance] In. Indonesia: The Wahid Institute.

. 2014. "Laporan tahunan kebebasan beragama / berkeyakinan dan intoleransi 2014." [2014 annual report on freedom of religion / belief and issues of intolerance]. In. Jakarta: The Wahid Institute.

Tuasikal, Rio, and Ninik Yuniati. 2018. "Kemendikbud: Sekolah Harus Berupaya Cegah Radikalisme." KBR, Accessed 13 April. http://kbr.id/nasional/042017/kemendikbud_sekolah_harus_berupaya_cegah_radikalisme/89670.html.

Wood, B. E. 2013. "Young People's Emotional Geographies of Citizenship Participation: Spatial and Relational Insights." Emotion, Space and Society 9: 50-58.

Wood, B. E. 2014. "Researching the Everyday: Young People's Experiences and Expressions of Citizenship." International Journal of Qualitative Studies in Education 27 (2): 214-232. doi:10. 1080/09518398.2012.737047.

Wood, B. E. (2017). Youth studies, citizenship and transitions: Towards a new research agenda. Journal of Youth Studies, 20(9), 1176-1190. doi:10.1080/13676261.2017.1316363

Yuval-Davis, N. 1999. "The Multi-Layered Citizen." International Feminist Journal of Politics 1 (1):119-36. 